\title{
Freshwater Diatomite Deposits in the Western United States
}

reshwater diatomite deposits in
the Western United States are
found in lake beds that formed mil-
lions of years ago. These diatom-rich
sediments are among the Nation's
largest commercial diatomite
deposits. Each deposit contains
billions of tiny diatom skeletons,
which are widely used for filtra-
tion, absorption, and abrasives.
New studies by the U.S. Geological
Survey (USGS) are revealing how
ancient lakes in the Western States
produced such large numbers of
diatoms. These findings can be used
by both land-use managers and
mining companies to better evaluate
diatomite resources in the region.

Diatoms are a type of single-celled algae found in lakes, streams, and oceans. They are abundant today and were common in many ancient environments. Diatom skeletons are a delicate lattice of silica $\left(\mathrm{SiO}_{2}\right)$, and each species has a distinctive skeleton. Diatom "blooms" can occur several times a year, and large blooms can produce billions of individual diatoms. The diatoms then die and their skeletons settle to the bottom of the water body.

In the geologic past, diatom accumulations in some lakes occurred over thousands of years, producing a thick layer called diatomite. Diatomite is a soft, very fine grained sedimentary rock with a chalk-like appearance. These silica-rich rocks are very finely porous and low in density - they will float on water until they become saturated.

Diatomite is used principally as a filter aid (for example, in the clarification of wine and beer) and also as a filler in a variety of products, insulation material, whitener in paint, abrasive in polishes, and silica additive in cement and various other compounds. It is also used as an absorbent for industrial spills and in pet litter. Because diatomite does not

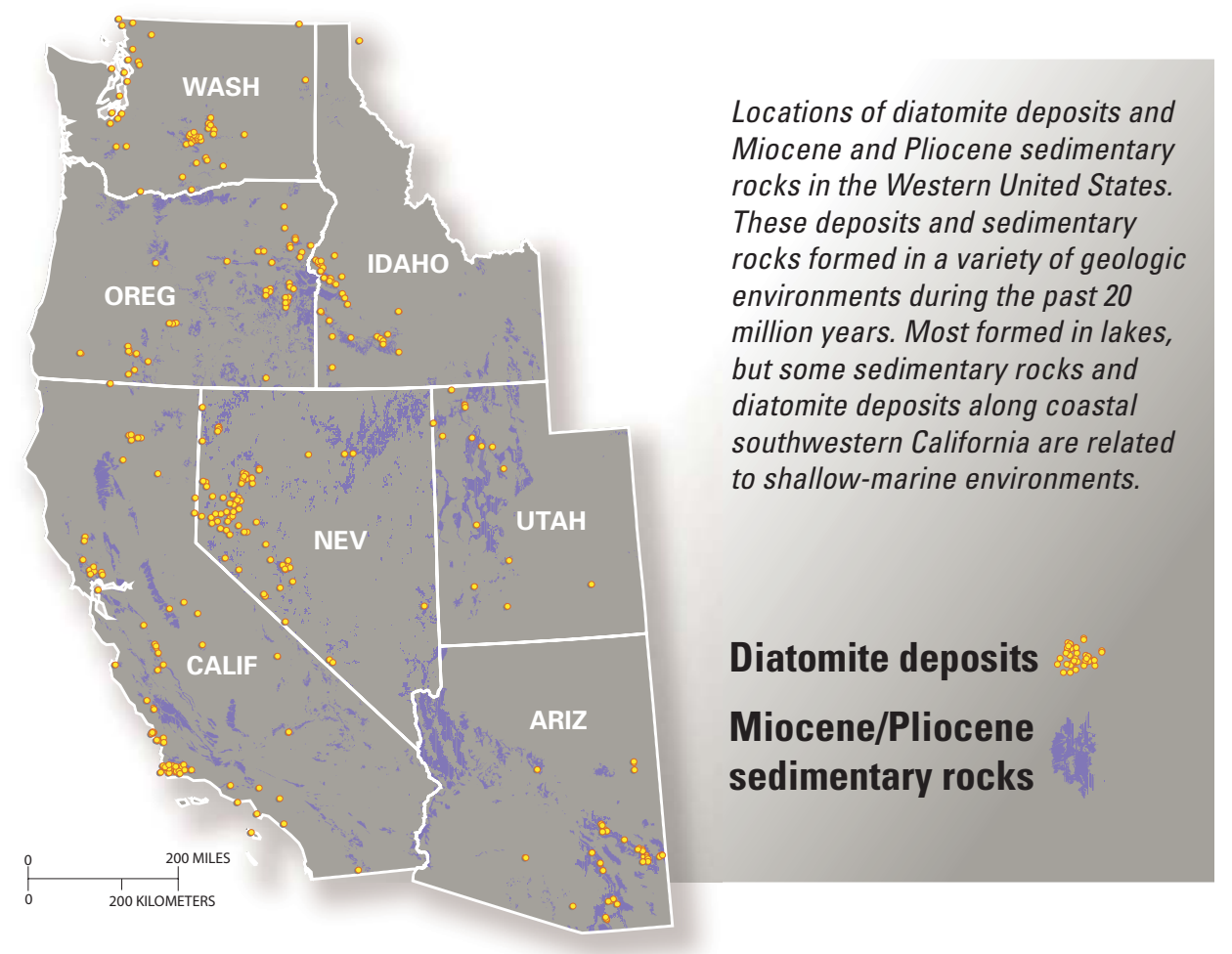

react with most chemicals, its usefulness is increased in many of these applications.

Diatomite is produced from large openpit mines. The commercial value and uses of diatomite depend on the purity and even the diatom species. In 2004, the United States accounted for approximately $30 \%$ of world diatomite production. This included 620,000 tons of diatomite valued at $\$ 177$ million mined in California, Nevada, Oregon, and Washington. More than two-thirds of the production in these States came from deposits that formed in freshwater lakes. Other important diatomite deposits, such as those in southern California, formed in shallowmarine settings.

Large deposits formed at the bottoms of many freshwater lakes in the Western United States during the Miocene and Pliocene epochs (24 to 2 million years ago). Many of these freshwater deposits are on public lands. To enhance the Nation's understanding of industrial minerals and to aid in the resource evaluation of these deposits, U.S. Geological Survey (USGS) scientists are studying the reasons why many ancient lakes produced such large diatomite deposits and why others did not.

\section{How Did Diatomite Deposits Form?}

Freshwater diatomites in the Western States formed over thousands to millions of years. The Miocene climate in the region was fairly mild and wet, but it gradually became drier in the late Miocene. Rain fell in the

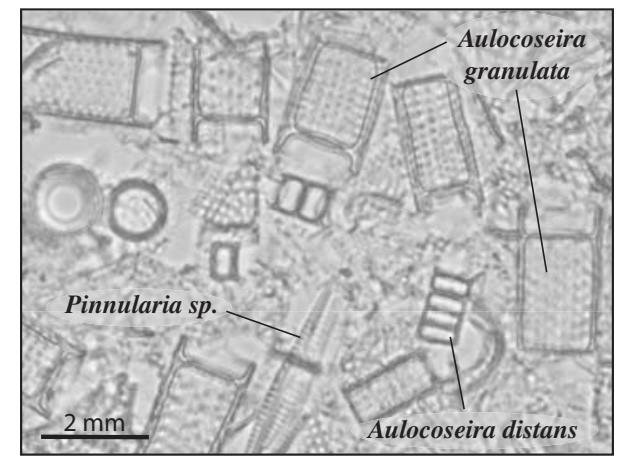

Diatoms that formed 15 million years ago in a lake near Carlin, Nevada, as seen through a high-powered microscope. The barrel-shaped and circular diatoms are members of the Aulocoseira genus, and the more elongate diatom is part of the Pinnularia genus. The 2-millimeter ( $\mathrm{mm})$ ( 0.08 inches) bar in the lower left indicates the very small size of the diatoms. 
FORMATION OF A FRESHWATER DIATOMITE DEPOSIT

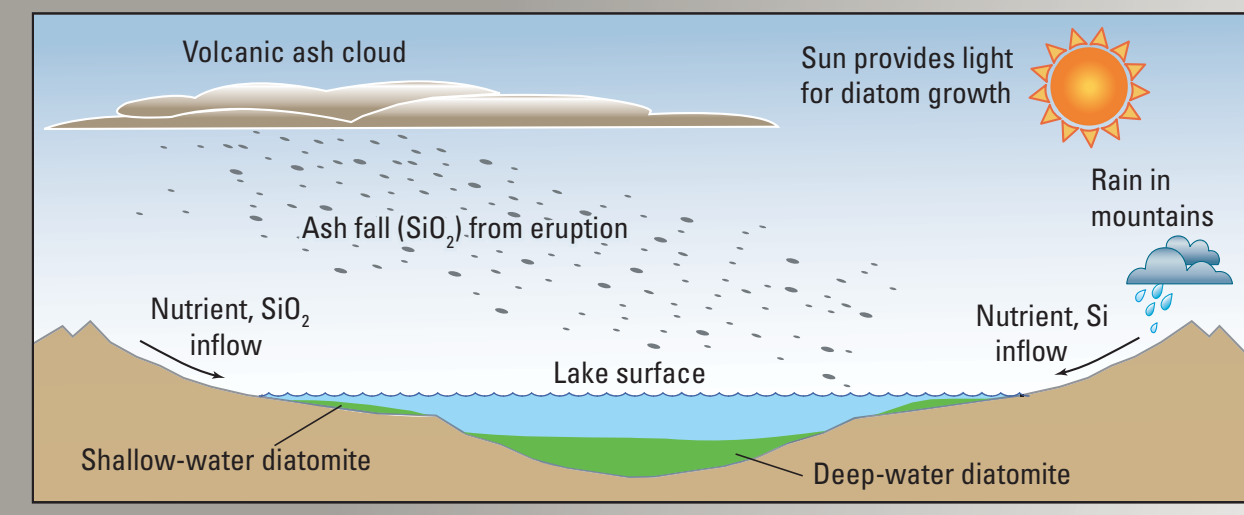

This diagram shows the setting of diatomite deposits in a lake and some of the processes that aided their formation. Rainfall produces streams that carry silica $\left(\mathrm{SiO}_{2}\right)$ and other nutrients, such as phosphorus $(P)$, into the lake from nearby highlands. Silica also can enter the lake in air-fall ash that was erupted from volcanoes and deposited on the lake's surface. Sunlight provides light for photosynthesis, which enables the diatoms to grow and bloom. After the diatoms bloom and die each year, their silica skeletons settle to the bottom of the lake and form a thin sedimentary layer. Over thousands of years, these layers accumulate to form a diatomite deposit. Diatomite deposits can form both in the shallow (littoral) and deeper (benthic) parts of the lake. Different species of diatoms prefer each environment, and the resulting diatomite deposits in the two locations can differ as a result. mountains, and streams carried the water down into lowlands, some of which had natural dams and thus contained lakes. The streams also carried important nutrients, such as phosphorus, from the hills into the lakes.

Miocene and Pliocene lakes in the Western States formed in a variety of ways. Very commonly, eruption of lava flows dammed streams and produced lakes. This happened in east-central Washington, where extensive flows of the middle Miocene Columbia River Basalt were erupted over a span of several millions years, producing lakes behind the volcanic dams. Other lakes in the Western States formed when fault movements blocked stream flow. The various lakes were present for a few thousand to several million years before the dams failed or were breached, the basin was filled by additional volcanic flows, or the lake simply dried up.

Diatoms thrive and bloom in many different types of water and at different water depths. Diatoms in these ancient freshwater lakes bloomed both near shorelines and in the middle of the lakes, many of which were neither acidic nor alkaline, very much like tap water. Some lakes in the region were shallow and alkaline and did not produce significant diatomite deposits, although zeolites, another important group of industrial minerals, formed in the sediments at the bottoms of these alkaline lakes.

Diatom activity relies on an influx of silica and nutrients. Silica is needed to form their skeletons, and it can come from several sources. Volcanic ash, produced from nearby and distant eruptions, lands on and settles through a lake and can react with the water, releasing silica. Dissolved silica also is washed into lakes by streams, either from weathering rocks or breakdown of silica-rich grasses in stream headwaters. All of these sources contributed needed silica to Miocene and Pliocene lakes in the Western States. However, ash from hundreds of eruptions spaced closely in time landed on some lakes, thereby limiting the time needed to form a thick diatomite deposit.

On the basis of studies of modern diatom growth, the most important nutrient is phosphorus $(\mathrm{P})$. Most $\mathrm{P}$ is derived from weathered rocks in nearby highlands and is carried into a lake by streams. Deposition of P-rich ash also can contribute $\mathrm{P}$ to a lake. Current research for this project indicates a strong correlation between $\mathrm{P}$ rich basaltic to andesitic volcanic rocks in the nearby highlands and the presence of a large diatomite deposit in the adjacent lake. Other P-rich rocks, such as shale and some limestone, also may have contributed $\mathrm{P}$ to some lakes. Lakes that did not have P-rich

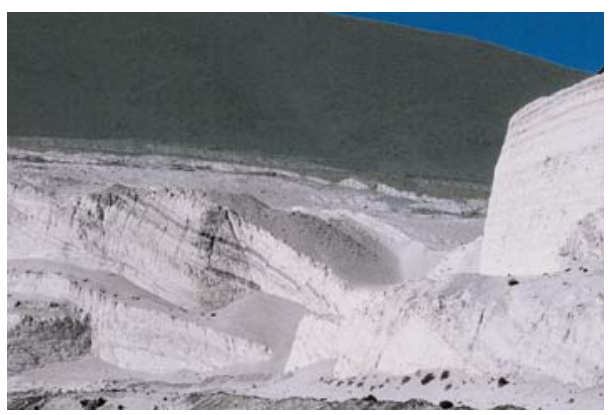

The Clark Station diatomite mine east of Reno, Nevada. The white areas are a 200-foot-thick pure diatomite that formed in a Miocene lake about 10 million years ago. Gray bands through the diatomite are beds of ash that formed when ash from volcanic eruptions was deposited onto the lake's surface and settled to the bottom. The lake beds originally were horizontal, but later fault movement tilted the beds. rocks in the surrounding highlands generally did not produce diatomite deposits.

\section{Resource Summary}

The formation of a diatomite deposit in a freshwater lake requires that many processes take place in and adjacent to the lake. The absence of one or more of these processes can limit or prevent the growth of diatoms and thus the formation of a thick diatomite deposit. Indeed, far more lacustrine sediments in the Western States do not contain diatomite deposits, or contain only small deposits, than contain deposits of commercial value.

Identifying the processes that formed economically large diatomite deposits is an important goal of the Sources of Industrial Minerals in the Western States Project. These results can be used by the diatomite industry to search for and evaluate new diatomite deposits, many of which may be present on public lands, and by land-use managers to plan for diatomite-mining-related activities. The results also further knowledge about ancient climate ("paleoclimate") and landscape evolution in the Western States and have important applications to studies of ground water and of other types of mineral deposits.

Alan R. Wallace, David G. Frank, and Alan Founie Edited by James W. Hendley II Graphic design by Judy Weathers

For further information contact:
Alan R. Wallace
U.S. Geological Survey, MS 176
University of Nevada, Reno
Reno, NV 89557-0047
(775) 784-5789
http://minerals.usgs.gov/west/
This Fact Sheet and any updates to it are available
online at
http://pubs.usgs.gov/fs/2006/3044

